\title{
Character Education According To Ki Hadjar Dewantara's View in Forming Gold Generations in The Era of Industrial Revolution 4.0
}

\author{
Sanudin Ranam \\ The Jakarta Islamic University of Jakarta. \\ Correspondent: s.ranam77@gmail.com
}

Submitted : Juny 30, 2020 Revised : July 15, 2020 Published : Juli 30, 2020

\begin{abstract}
The era of the industrial revolution 4.0 that is currently happening is marked by the rush of digitalization and automation which causes humans to not be separated from gadgets and the internet. Humans are subjects who play a role in regulating and determining that connectivity. People who have strong character will successfully develop connectivity in internet-based networks. Innovative, creative, honest, disciplined traits are required to exist in a network. That is why character education for our students is so necessary. Several research results show that the teachings and thoughts of Ki Hadjar Dewantara or Tamansiswa teachings are still very relevant to education today, this is because Ki Hadjar Dewantara teaches various things in shaping the character of the nation and is very down to earth and rooted in Indonesian culture, including Tutwuri Handayani, Pancadharma, Among, which is based on Trikon (continuity, convergence, and concentricity), Tripusat education (family, school, community), Tringga (Ngerti, Ngrasa, Nglakoni).
\end{abstract}

Keywords: Industrial Revolution 4.0, Character Education, Ki Hadjar Dewantara

\section{INTRODUCTION}

Currently, the world has entered the era of the 4.0 generation industrial revolution marked by increased connectivity, interaction and development of digital, artificial intelligence and virtual systems. With the increasingly convergent boundaries between humans, machines and other resources, information and communication technology will certainly have an impact on various sectors of life. One of them is having an impact on the education system in Indonesia. [1]

The change in this era cannot be avoided by anyone, so that adequate preparation of human resources (HR) is needed to be ready to adjust and be able to compete on a global scale. Improving the quality of human resources through education from primary and secondary education to higher education is the key to being able to keep up with the development of the Industrial Revolution 4.0. However, it should be understood that the effects of globalization are likened to two different sides of money which have positive and negative impacts. Positive impacts, for example, encouraging new professions such as YouTubers, Bloggers, Influencers, and others, while one of the negative impacts is the rampant violence, drug abuse, free sex, and crime (Barmawi \& M. Arifin, 2012). [2]

Sadly, this behavior is also practiced by many elementary school aged children. This can be seen in several reports in the mass media, the internet (youtube), newspapers and television, where it can be seen that elementary school-age children have dared to make mistakes such as smoking, stealing, pornographic acts, committing immoral acts, forcibly asking for money from his friend, drinking mixed alcohol and there are still several other forms of delinquency. Some examples of 
Character Education According To Ki Hadjar Dewantara's View In Forming Gold Generations In The Era Of Industrial Revolution 4.0

Ranam

the news show that education in Indonesia has not been fully able to build the character of students, educational praxis that occurs in classrooms is nothing more than scholastic exercises, such as recognizing, comparing, training and memorizing, namely very simple cognitive abilities, at the level. the lowest (Surakhmad:2003). H.A.R. Tilaar (2012: 57) emphasizes that educational praxis is not only knowledge about socio-culture from students. The science of education and methodology that can be either in scientific books or in educational praxis come from western sources. Strengthening the opinion of Tilaar, Wangid (2009) who said that so far education, especially in schools, has applied more education and learning systems and methods originating from western countries, which are not necessarily in accordance with the needs and culture of Indonesia. many forget that the Indonesian nation has indigenous Indonesian education systems and methods, various thoughts and ideas of Ki Hadjar Dewantara, which have also been applied through Taman Siswa education. We are more familiar with foreign theories about education (Tilaar, 2015). [3]

Ki Hadjar Dewantara's educational thinking is actually not inferior to modern educational ideas and theories. For example, Ki Hadjar Dewantara introduced the Tri-Nga concept which consists of Cognitive ( Ngerti), Affective ( Ngrasa) and Psychomotor ( Nglakoni ) from Taxonomy Bloom (cognitive, affective, psychomotor), even though Ki Hadjar Dewantara's concepts are actually implemented. in Tamansiswa, which was established on July 3, 1922, while Taxonomy Bloom was introduced in 1956 by Dr. Benjamin Bloom. This is proof that Ki Hadjar Dewantara's thinking is not inferior to western scientists (Subekti, NB: 2015).

Why he refers to Ki Hadjar, is because Ki Hadjar Dewantara is a figure of the Indonesian nation, an educational figure who teaches many things in shaping the character of the nation and is very down to earth and rooted in the culture of the archipelago, including Tutwuri Handayani, Pancadharma, Among, which is based on Trikon ( continuity, convergence and concentricity), Tripusat education (family, school, community), Tringa (Ngerti, Ngrasa, Nglakoni), so that he is known as a warrior, true educator and at the same time Indonesian cultural observer. This is reinforced by Abuddin Nata in (Muthoifin \& jinan, 2015) that the problem of education in general cannot be abandoned by talking to a character named Ki Hadjar Dewantara, an expert who is involved and concentrates his expertise in the field of education. [4] With this, due to various strategic concepts about education in Indonesia, almost all aspects refer to his thinking.

Unfortunately, in its development education actually loses its spirit and enthusiasm, so that it is trapped in achieving narrow targets, and the embodiment of the good character of the nation is neglected, and what is more ironic is what Anies Baswedan said that when in other countries (Finland) applied the principles of Ki Hadjar Dewantara's teaching principles and success in improving their educational performance ... when we ourselves are alienated from their thoughts (Intisari_online.com, 2015).

Seeing this fact, the role of the teacher / tutor as the second parent while at school has a very important role in shaping the character of students. Teachers are required to better prepare their roles in integrating social and cultural capital in every learning activity process that is oriented towards investment and personality, character, and character, either through extracurricular or intracurricular activities.

\section{METHODS}

The approach used in this research is a qualitative approach, namely research procedures that produce descriptive data in the form of references or writing and behaviors that can be 
Character Education According To Ki Hadjar Dewantara's View In Forming Gold Generations In The Era Of Industrial Revolution 4.0

Ranam

observed from the person (subject) itself. [14] With this qualitative research, the researcher will make a descriptive description of the object being studied systematically, both regarding the facts, characteristics and various things related to the research theme. Qualitative analysis is considered more appropriate in this study, because this analysis is expected to make it more possible to develop this research in order to gain a deeper understanding.

\section{RESULTS AND DISCUSSION}

\section{Concept of Character Education from Ki Hadjar Dewantara's perspective}

Ki Hadjar Dewantara is a thinker of modern education and is also known as the Father of Indonesian National Education, which is known for his concept of educational institutions which still exist today, namely the Tamansiswa National College which was founded in Yogyakarta on July 3, 1922. In an eye event, Najwa broadcast by a private television station on 26 November 2015, an event entitled "Learning from Ki Hadjar Dewantara '. Educational activist Bukik Setiawan said that Ki Hadjar Dewantara's thoughts were very updated in his time and even beyond his era. Western education thinkers such as Montessory in the 1940s visited the Tamansiswa College to study at Ki Hadjar Dewantara. Ki Hadjar Dewantara's idea is actually widely used in European countries such as Finland, which is currently known as the country with the best education system in the world.

According to Ki Hadjar Dewantara, Montessory and Tagore are the dismantlers of the old world of education and the builders of a new genre, which nota bene is that the new flow is in line with the Indonesian nation because it is based on socio-culture. Montesorry and Tagore consider that education and teaching in Europe nourishes intellectuality, but it numbs feelings, thus turning the mind into a mere machine. (Abdurrahman Suryomihardjo, 1986: 74).

Educating according to Ki Hadjar Dewantara in the real sense is the process of humanizing humans (humanization), namely the elevation of humans to the human level. So in educating, there is learning which is an authentic communication of human existence to humans, to be owned, continued and perfected. This can be seen from the writing of Ki Hadjar Dewantara (2009: 59) entitled Human beauty:

"Humans are virtuous creatures, while budi means a soul that has passed a certain intelligence level, thus showing a clear difference from the souls of animals. If the animal contains only natural passions, impulses and desires, instincts and other powers are not powerful enough to resist forces, whether they come from outside or from within the soul. The animal soul is solely capable of carrying out the necessary actions to maintain its very simple necessities of life, for example eating, drinking, sounding, running and so on ".

Based on the above statement, it can be seen that Ki Hadjar Dewantara puts forward "humanization" so that education is the process of humanizing humans so that they become human / virtuous beings. [5]

In the concept of education, Ki Hadjar Dewantara distinguished between "teaching" and "education" systems which had to work in synergy between one another. Teaching liberates humans from the outer aspects (poverty and ignorance), while education frees humans more from the inner aspect of life. Thus a free human being is a person who is free physically and spiritually and is not dependent on other parties and is able to stand on his own feet, which means that in the education system, each individual must be independent and think for himself.

According to Siswanto, in the book Sari Pati Pemikiran Ki Hadjar Dewantara said that the education and teaching of $\mathrm{Ki}$ Hadjar Dewantara cannot be equated with education and learning in 
Character Education According To Ki Hadjar Dewantara's View In Forming Gold Generations In The Era Of Industrial Revolution 4.0

Ranam

western literature. The educational vocabulary was emphasized by Ki Hadjar Dewantara to mark the process of cultivating a child's soul and spiritual atmosphere, to liberate and liberate the child's soul so that he was able to create, work, and have initiatives as a resistance to the colonial education system which only emphasized intellectualistic, materialistic, and individualistic. So Ki Hadjar Dewantara emphasized that character education is prioritized (Tamansiswa, 2015: 66). Ki Hadjar Dewantara in Pusara magazine (February 1954) in Cahyono (2017: 54) wrote an article entitled "Teaching Characteristics" which basically states that character education is really needed or must be delivered to students by all teachers in schools ". [6]

Several labels in the scientific scope related to the term character education include moral education, character education, civilization education and moral education. Ki Hadjar Dewantara used the term character education for moral and civilized education.

Education in the concept of Ki Hadjar Dewantara means the effort to advance the growth of the students' noble character (inner strength, character), mind (intellect) and the child's body. In the meaning of Tamansiswa, the three of them cannot be separated, in order to advance the "perfection of life", namely the life and livelihood of the children we educate in harmony with their world (Ki Hadjar Dewantara, 1977: 14-15). [7] Thus character education is an integral part that cannot be separated from education so that we can advance the perfection of our children's lives ...". From this, it can be seen that Ki Hadjar Dewantara has his own concept in character education for children, so education is not only intellectually intellectual, but also builds a good personality.

Based on this, teachers as moral agents must strive for character education so that students have positive characters. As expressed by Lickona (1991: 53), "There are many different kinds of moral knowing we need to draw on as we deal with life's moral challenges. The following six stand out as desirable goals of character education ". According to Lickona, having knowledge of moral values is not enough to become a human with character, moral values must be accompanied by moral character. [8]

Another definition put forward by Agus (2012: 33) states that character education is character education plus, which involves aspects of knowledge (cognitive), feeling (feeling), and action (action). In line with Agus, according to Muchlas Samani and Hariyanto in the Holistic Journal (Sopindi, 2014: 295), he explains that character education is a process of giving demands to students to become whole human beings who have character in the dimensions of heart, mind, body, and feeling and intention. Character education is often referred to as value education, character education, moral education, character education, which aims to develop the ability of students to make good and bad decisions, maintain what is good, and realize that good in everyday life wholeheartedly. The character-based education system has three psychological contents, namely moral reasoning, moral feeling, and moral behavior (action). [9]

Character education raises universal values that can be accepted by different religious, cultural and traditional backgrounds, not only raising theory but also its application in society. The term put forward by Lickona in the teachings of Taman Siswa is known as Tiga Ng or Tri Nga, namely: Understanding (knowing) it means that the purpose of education is to increase students' knowledge of what is being learned, Ngrasa (understanding) which means sharpens a sense of understanding about what is known, and Nglakoni (doing), namely increasing the ability to carry out what is learned. So in essence in character education is a process to form, grow, develop and mature the child's personality into a wise and responsible person through habituation of thoughts, hearts and actions on an ongoing basis whose results can be seen in real daily actions both in 
Character Education According To Ki Hadjar Dewantara's View In Forming Gold Generations In The Era Of Industrial Revolution 4.0

Ranam

school. and in society. [10] Ki Hadjar Dewantara as conveyed by the Governor of the Special Region of Yogyakarta at the National Seminar at Taruna Nusantara High School (2018) "Habituating" can be done by implementing the tri-nga model (Ngerti $=$ understand, Ngrasa $=$ feel, Nglakoni- do), which means principle character education is to instill good habits (habituating), so that students understand, are able to feel, and want to do good things.

Thus, Tringa's teachings from Ki Hajar Dewantara are in line with the concepts conveyed by Bloom, namely the cognitive, affective and psychomotor aspects. Although according to several sources it is known that the concept of Ki Hadjar Dewantara has existed since 1922, while Bloom's taxonomy was only discovered in 1956 (Subekti, N.B: 2015). [11] Therefore education should not only prioritize the development of cognitive and psychomotor aspects, but also must pay attention to the affective aspects which include character education or character.

Based on some of the opinions above, it can be concluded that character education is a system of the process of providing guidance to form habits for students to become fully human with character.

Such is the importance of character education, so that Ki Hadjar Dewantara made this the soul of his educational concept. The teachings of Ki Hadjar Dewantara consisted of several conceptual matters, practical-operational instructions, fatwas, advice and so on. [12] Here are some of the teachings of Ki Hadjar Dewantara (Ki B. Boentarsono, et al: 19-23): here are some concepts and teachings from Ki Hadjar Dewantara:

\section{Right to claim greetings and happiness}

Everyone has the right to happiness and prosperity where self-happiness should not violate the peace of society.

\section{System Among}

The among system is an implementation of the principle of self-independence, orderly and peaceful society. The among system is an education system with a family spirit and based on the nature of nature and independence (MLPTS [Majelis Luhur Tamansiswa], 2012).

\section{Tri nga (Ngerti, ngrasa, nglakoni)}

This teaching reminds us of all the teachings of life or our aspirations that require understanding, awareness and seriousness in their implementation, knowing and understanding is not enough if we don't realize it and it is meaningless if we don't implement it and fight for it. Knowledge without charity is empty and charity without knowledge is a lie / lame (Team Lecturer Ketamansiswaan, 2014).

\section{Leadership Trilogy}

In the educational process, every teacher / pamong as a leader must be good at placing himself in various situations in order to carry out his role as best as possible so that students have good character, namely by implementing: "Ing Ngarsa Sung Tulada, Ing Madya Mangunkarso and Tut Wuri Handayani, which means that as a teacher must be able to provide role models for his subordinates or subordinates both in words and deeds, provide encouragement and motivation to students to develop their interests and talents so that they can work creatively and come up with productive ideas and must also provide moral and morale from behind ". A teacher follows from behind with full responsibility and care giving freedom, opportunity and also guidance so that students can develop according to their own nature "(Moh. Yamin (Wulandari, 2016). [13] 
Character Education According To Ki Hadjar Dewantara's View In Forming Gold Generations In The Era Of Industrial Revolution 4.0

Ranam

\section{Tri Education Center}

Character education will not work well if only one education center is running if it is not supported by three education centers, namely family, school and community). In its implementation, the three education centers must have good cooperation in educating students to be able to grow and behave well. Families must be able to communicate well with schools and provide information to each other regarding their child's development at home. In addition, schools must always receive input and suggestions related to the learning process that has been carried out by the guardian's parents. Not only that, society in general also has to provide a good environment so that children can be emulated as to what kind of social and interaction they should be in society. The community must also play an active role to provide input to schools and communicate well with families and other communities to work together to educate children in any environment.

Regarding how Ki Hadjar Dewantara educates it is called "educational equipment". According to Ki Hadjar Dewantara, there are many ways to educate, but there are several examples that should be noted, namely: (a) Give an example; (b) Habit; (c) Teaching; (d) (Orders, coercion and punishment) $* *$ Is a method against which Ki Hadjar Dewantara; (e) Salable; and (f) Physical and mental experiences (nglakoni, ngrasa) (Ki Hadjar Dewantara in the Great Tamansiswa Council, 1977: 28). [14]

\section{CONCLUSION}

Entering the era of the industrial revolution 4.0, the visionary teachings and thoughts of Ki Hadjar Dewantara are still very relevant for forming a superior generation and with the character of students. [15] Ki Hadjar Dewantara's teachings support the educational revolution (4.0) as long as it raises a noble, refined, easy, pleasant culture and advances education itself. [16] pious, faithful, honest, trustworthy, just, responsible, empathetic, self-sacrificing, patriotic, and Nationalist; Aesthetic (aesthetic) character can develop Friendly, respectful, tolerant, caring, like helping and mutual cooperation, thinking (literacy) fosters intelligent, critical, creative, innovative, curious, open-thinking, productive, science-oriented and reflective characters; and sports (kinesthetic) to develop clean and healthy characters, discipline, sportsmanship, toughness, reliability, endurance, friendly, cooperative, determinative, competitive and persistent and cheerful.

This harmony is taken from the Trisakti Jiwa concept taught by Ki Hadjar Dewantara in the concept of culture, which consists of creativity, taste and intention. The concept is the three forms of strength contained in the human soul itself, namely thought, feeling and will, using the among system by instilling habituating among, while still optimizing the role of the Tri Pusat Pendidikan.

\section{REFERENCES}

[1] Lase, D. (2019). Pendidikan di Era Revolusi Industri 4.0. SUNDERMANN: Jurnal Ilmiah Teologi, Pendidikan, Sains, Humaniora Dan Kebudayaan. https://doi.org/10.36588/sundermann.v1i1.18

[2] Zulfiati, H. M. (2019). PENDIDIKAN KARAKTER PERSPEKTIF KI HADJAR DEWANTARA DALAM MEMBENTUK GENERASI UNGGUL ERA REVOLUSI INDUSTRI 4.0. Prosiding Seminar Nasional PGS.

[3] Tilaar. (2002). Pendidikan, Kebudayaan, dan Masyarakat Madani Indonesia; Strategi Reformasi Pendidikan Nasional. In Ketiga. 
Character Education According To Ki Hadjar Dewantara's View In Forming Gold Generations In The Era Of Industrial Revolution 4.0

Ranam

[4] Muthoifin, M. J. (2015). PENDIDIKAN KARAKTER KI HADJAR DEWANTARA: STUDI KRITIS PEMIKIRAN KARAKTER DAN BUDI PEKERTI DALAM TINJAUAN ISLAM. Profetika: Jurnal Studi Islam.

[5] Dewantara, K. H. (1967). Karya Ki Hadjar Dewantara. In Kebudayaan. https://doi.org/10.1109/INFCOMW.2009.5072193

[6] Haryanto. (2013). Pendidikan Karakter menurut Ki Hadjar Dewantara. Journal of Chemical Information and Modeling. https://doi.org/10.1017/CBO9781107415324.004

[7] Darmawan, I. P. A. (2016). Pandangan dan Konsep Pendidikan Ki Hadjar Dewantara. Prosiding Seminar Nasional Dan Bedah Buku FKIP UKSW.

[8] Lickona, T. (2013). Character education: The cultivation of virtue. In Instructional-Design Theories and Models: A New Paradigm of Instructional Theory. https://doi.org/10.4324/9781410603784-32

[9] Asa, A. I. (2019). PENDIDIKAN KARAKTER MENURUT KI HADJAR DEWANTARA DAN DRIYARKARA. Jurnal Pendidikan Karakter. https://doi.org/10.21831/jpk.v9i2.25361

[10] Sukri, Handayani, T., \& Tinus, A. (2016). Analisis Konsep Pemikiran Ki Hajar Dewantara Dalam Perspektif Pendidikan Karakter. Jurnal Civic Hukum.

[11] Susilo, S. V. (2018). REFLEKSI NILAI-NILAI PENDIDIKAN KI HADJAR DEWANTARA DALAM UPAYA MENGEMBALIKAN JATI DIRI PENDIDIKAN INDONESIA. Jurnal Cakrawala Pendas. https://doi.org/10.31949/jcp.v4i1.710

[12] Dewantara, K. H. (1967). Karya Ki Hadjar Dewantara. In Kebudayaan. https://doi.org/10.1109/INFCOMW.2009.5072193

[13] Dyah. (2012). Kajian Konsep Pendidikan Karakter Menurut KH Ahmad Dahlan dan Ki Hadjar Dewantara: Suatu Refleksi Historis Kultural. Konaspi VII Universitas Negeri Yogyakarta.

[14] Wijayanti, D. (2018). CHARACTER EDUCATION DESIGNED BY KI HADJAR DEWANTARA. EduHumaniora | Jurnal Pendidikan Dasar Kampus Cibiru. https://doi.org/10.17509/eh.v10i2.10865

[15] Tohir, M. (2016). Sosok Guru Profesional yang Ideal Ala Ki Hajar Dewantara. Tersedia Online: Http://Pasca.Unej.Ac.Id/Sosok-Guru-Profesional-Yang-Ideal-Ala-Ki-HajarDewantara/ [02 Mei 2016].

[16] Mashari, F., \& Qomariana, A. (2016). Prespektif Pemikiran Ki Hadjar Dewantara dalam Pendidikan Karakter dan Kaitannya dengan Pendidikan Islam. Dirāsāt: Jurnal Manajemen Dan Pendidikan Islam.

[17] Suwahyu, I. (2019). PENDIDIKAN KARAKTER DALAM KONSEP PEMIKIRAN PENDIDIKAN KI HAJAR DEWANTARA. INSANIA : Jurnal Pemikiran Alternatif Kependidikan. https://doi.org/10.24090/insania.v23i2.2290

[18] Mujito, W. E. (2014). Konsep Belajar Menurut Ki Hadjar Dewantara dan Relevansinya dengan Pendidikan Agama Islam. Pendidikan Agama Islam.

[20] Zulfiati, H. M., \& Chairiyah. (2017). Implementation of Cultural school as Character Education based on Ki Hadjar Dewantara in Elementary school. N 2017 International Converence on Education and Science (Icons 2017).

[21] Hadliansah, D. H. \& J. (2016). Menggali Ideologi Ki Hajar dalam Pendidikan Seni. ResearchGate. https://doi.org/10.13140/RG.2.1.2760.8086 
Character Education According To Ki Hadjar Dewantara's View In Forming Gold Generations In The Era Of Industrial Revolution 4.0

Ranam

[22] Putu Ayub, I. D. (2017). Pandangan dan Konsep Pendidikan Ki Hadjar. Prosiding Seminar Nasional Dan Bedah Buku. https://doi.org/10.1136/sextrans-2014-051772

[23] Wijayanti, D. (2018). CHARACTER EDUCATION DESIGNED BY KI HADJAR DEWANTARA. EduHumaniora | Jurnal Pendidikan Dasar Kampus Cibiru. https://doi.org/10.17509/eh.v10i2.10865

[24] Nasrulloh, A. (2015). Pendidikan Menurut Ki Hajar Dewantara.

[25] Mudana, I. G. A. M. G. (2019). MEMBANGUN KARAKTER DALAM PERSPEKTIF FILSAFAT PENDIDIKAN KI HADJAR DEWANTARA. Jurnal Filsafat Indonesia. https://doi.org/10.23887/jfi.v2i2.21285

[26] Nugroho, W. (2018). Implementasi Trilogi Ki Hadjar Dewantara di SD Taman Muda Jetis Yogyakarta. Edukasi Journal. https://doi.org/10.31603/edukasi.v10i1.2031

[27] Nugroho, W. (2018). Implementasi Trilogi Ki Hadjar Dewantara di SD Taman Muda Jetis Yogyakarta. Edukasi Journal. https://doi.org/10.31603/edukasi.v10i1.2031

[28] Haryanto. (2013). Pendidikan Karakter menurut Ki Hadjar Dewantara. Journal of Chemical Information and Modeling. https://doi.org/10.1017/CBO9781107415324.004

[29] Musanna, A. (2017). INDIGENISASI PENDIDIKAN : Rasionalitas Revitalisasi Praksis Pendidikan Ki Hadjar Dewantara INDIGENIZING EDUCATION: Rationalization toward Revitalization of Ki Hadjar Dewantara Educational Praxis. Pendidikan Dan Kebudayaan.

[30] Marwah, S. S., Syafe'i, M., \& Sumarna, E. (2018). RELEVANSI KONSEP PENDIDIKAN MENURUT KI HADJAR DEWANTARA DENGAN PENDIDIKAN ISLAM. TARBAWY: Indonesian Journal of Islamic Education. https://doi.org/10.17509/t.v5i1.13336

[31] Mujito, W. E. (2014). Konsep Belajar Menurut Ki Hadjar Dewantara dan Relevansinya dengan Pendidikan Agama Islam. Pendidikan Agama Islam.

[32] Henricus Suparlan. (2015). Filsafat Pendidikan Ki Hadjar Dewantara. Jurnal Filsafat.

[33] Muhali. (2018). Arah Pengembangan Pendidikan Masa Kini Menurut Perspektif Revolusi Industri 4.0. Prosiding Seminar Nasional Lembaga Penelitian Dan Pendidikan (LPP) Mandala. 